\title{
Capitalization of Resources of Oil and Gas Fields
}

\author{
Uliana Vytvytska* \\ Department of Finance \\ Ivano-Frankivsk National Technical \\ University of Oil and Gas \\ Ivano-Frankivsk, Ukraine \\ uliana2176@gmail.com
}

\author{
Yaroslav Vytvytsky \\ Department of of Applied Economics \\ Ivano-Frankivsk National Technical \\ University of Oil and Gas \\ Ivano-Frankivsk, Ukraine \\ vytvytsky3947@gmail.com
}

\author{
Igor Andriichuk \\ Department of Applied Economics \\ Ivano-Frankivsk National Technical \\ University of Oil and Gas \\ Ivano-Frankivsk, Ukraine \\ igorandriichuk7@gmail.com
}

\begin{abstract}
The article is devoted to the development of methodological approaches to the capitalization of resources of oil and gas fields in the subsoil. A new methodological approach to the capitalization of oil and gas resources has been developed that combines a differentiated accounting of investment characteristics, cash flow generation, their use and consideration of the influence of the time factor at various stages of the long life cycle of exploration and development of oil and gas fields. For this purpose, it has been proposed to divide the life cycle of oil and gas resources development into three periods - the period of investment costs (exploration, drilling, field development), the payback period of investments and the main operational period. For each period, appropriate methods are provided for determining the influence of the time factor, taking into account natural and geological features, as well as the risks of investing and receiving cash flows during the development of oil and gas resources.
\end{abstract}

Keywords-capitalization, cash flow generation, discount rate, oil and gas resources, time factor

\section{INTRODUCTION}

When involving natural resources, including oil and gas, in economic activity, their financing is of decisive importance, and capitalization processes play a key role in it. Indeed, increasing the capitalization of assets is considered as one of the main strategic goals of any economic activity in modern market conditions. Therefore, an important task is the development of methodological approaches that would allow, based on the use of modern achievements of economic science, to properly solve this problem.

\section{ANALYSIS OF RELATED RESEARCH AND PUBLICATIONS}

The study of the essence of capitalization processes has a long and multifaceted history. The conceptual basis of modern ideas about capitalization processes was the work of the classics of economic theory K. Marx, J. Keynes, I. Fisher. The beginning of the XXI century was characterized by the expansion of the scope of the concept and procedure of capitalization. They began to use it to study the efficiency of use not only of individual assets, enterprises, but also of individual cities, regions, countries. The development of the theory of capitalization in various aspects was studied by V. M. Geits [1], M. A. Kozoriz, G. V. Voznyak [2], I. P. Buleev [3], B. V. Burkinsky, V. F. Goryanchuk [4], M. G. Zinkovskaya, T. V. Raeva [5] O. V. Shimko [6], D. A. Alekseev [7], I. Y. Yaremko, O. S. Lemishovskaya [8], V. V. Zymovets, K. V. Bagatska [9] and others.

The problems of capitalization of natural resources are actively studied by scientists of the Institute of
Environmental Economics and Sustainable Development of the National Academy of Sciences of Ukraine, headed by M. A. Khvesyk [10]: S. I. Pyrozhkov [11], V. S. Mishchenko [12], I. K. Bystryakov [13, 14], V. M. Mandzyk [15].

As for the capitalization of oil and gas resources, it is necessary to pay attention to the methodological approaches proposed by O. V. Lebega [16].

Summarizing the results of theoretical studies, the following general definition of capitalization can be given: capitalization is a fundamental process and an integral indicator, the economic essence of which is to increase the cost of capital, both as a result of increasing assets and the efficiency of their use.

The capitalization of oil and gas resources is a cost reflection of the potential of the resources of oil and gas fields in the subsoil, taking into account the current price at the time of the assessment, technical and technological level of the project of development and the geological and economic risks specific to this field.

It should be noted that the main method of capitalization of most assets is the income approach, which is based on the method of discounting cash flows. This method is based on the concept of accounting for changes in the value of money over time, and which are influenced by numerous factors. Meanwhile, there have recently appeared more and more publications, in which the discounting method of cash flows is criticized $[17,18,19,20]$, since the application of the discounting procedure in the traditional form leads to a significant depreciation of future cash flows, which means a significant underestimation of the effectiveness of investments, especially projects with a significant implementation period of $5-10$ or more years. This is especially true for the oil and gas industry, where the development of oil and gas fields sometimes lasts for decades.

Therefore, U. Ya. Vytvytska proposed a fundamentally new approach and an appropriate model for assessing the effectiveness of innovative investment projects, which consists in using the positive aspects of traditional approaches and methods that take into account the time factor through discounting and compounding procedures [21].

In this paper, it is proposed to apply elements of this approach to the capitalization of oil and gas resources.

\section{THE PROPOSED METHODOLOGICAL APPROACH}

The essence of the proposed approach is as follows: the life cycle of exploration and development of oil and gas fields resources is divided into three periods: 
- the period of exploration and field development.

- the period of exploration and field development;

- $\quad$ payback period;

- $\quad$ after payback (main operating) period.

For each period, there should be applied:

- appropriate procedures of time factor accounting;

- $\quad$ various points in time for generation of cash flows;

- various discount rates that take into account specific risks and rates of income for each period [21].

In addition, when evaluating the effectiveness of largescale projects, especially those related to the development of mineral deposits, solving environmental and social problems, it is necessary to pay attention that such projects can lead to useful results in related fields of activity, forming both positive and negative externalities (external effects) [22, pp. 95-97].

Given the above, we offer the following model for the capitalization of oil and gas resources:

$$
\begin{gathered}
C_{O G R}=\left[\sum_{t=t_{I_{e}}}^{P P} \frac{P N P_{t}}{(1+r)^{t_{P P}}}+\sum_{t=P P+1}^{T c} \frac{\left(P N P d_{t}+P N P r_{t}\left(1+r_{b}\right)^{T e-t_{e}}\right)}{\left(1+r_{i}\right)^{t_{e}}}\right] k_{i} k_{d}- \\
-\left[\sum_{t_{I C}=0}^{T e} I_{t_{I C}}\left(1+r_{b}\right)^{T e,-t_{I C}}+\sum_{t=t_{R C F}}^{T_{C}} \frac{I_{t_{e}}}{\left(1+r_{b}\right)^{t_{e}}}\right]
\end{gathered}
$$

where $C_{O G R}$ is the cost of oil and gas resources;

$\boldsymbol{P N P}_{t}$ is part of the net profit generated as a result of the extraction and sale of oil and gas reserves for a certain calendar period of the development of the oil and gas field $t_{e}$;

$P N P d_{t_{i}}$ is part of the net distributed profit generated as a result of the extraction and sale of oil and gas reserves for a certain calendar period of the development of the oil and gas field $t_{e}$;

$P N P_{t_{i}}$ is part of the net retained profit generated as a result of the extraction and sale of oil and gas reserves for a certain calendar period of the development of the oil and gas field $t_{e}$

$I_{t_{I C}}$ - investment expenses during exploration, well drilling and field development in the $t^{\text {th }}$ year;

$I_{t_{e}} \quad$ - investment expenses during the operation of the oil and gas field in the $t^{\text {th }}$ year;

$k_{i}, k_{d}$ are correspondingly, increasing or decreasing correcting coefficients of external results that may arise from third parties who are not direct participants in innovation and investment projects, as a result of a decrease or increase in destructive environmental impacts, improvement or worsening of social conditions, etc. For example, these ratios can be determined by the data given in [22, pp. 95-97]; $r_{b}$ is the basic rate of return, which is defined as the average rate of return on foreign currency deposits in system banks of Ukraine at the time of capitalization;

$r_{i}$ is the discount rate that takes into account only the risks of investing in the development of resources of the estimated oil and gas field;

$r$ is the full discount rate that takes into account the risks of investing in the estimated oil and gas field and the risks of freezing investment resources due to the possibility of alternative capital investment $\left(r=r_{b}+r_{i}\right)$;

$t_{\text {IC }}$ is the current year of investment costs (geological and geophysical works, well drilling, field development);

$t_{R C F}$ is the year of the start of receiving cash flows from the development of the oil and gas field;

$t_{P P}$ is the current year of receipt of cash flows in the payback period, which varies within $t=t_{R C F}=1,2, \ldots, P P$;

$t_{e}$ is the current year of receipt of cash flows and economic benefits in the after payback period, which varies within $t_{e}=P P+1,2,3, \ldots, T c$;

Te is the time during which investments are made in exploration before the start of the commissioning of an oil or gas field;

$P P$ is the payback period of the oil and gas field development project, in years;

$T c$ is the year of completion of field development.

Part of the net profit $P N P_{t}$ is determined by the formula as follows:

$$
P N P_{t}=\sum_{i=1}^{n}\left(q_{t_{i}} P_{t_{i}}-C o_{t_{i}}-I T_{t_{i}}\right)-k\left(V_{F A_{t}}+V_{I A_{t}}\right)
$$

where $q_{t_{i}}$ is the volume of production of the $i^{\text {th }}$ useful component from the oil and gas field (oil, associated gas, natural gas, gas condensate, shale gas) in the $t^{\text {th }}$ year;

$n$ is the number of types of oil and gas resources extracted during field development;

$P_{t_{i}}$ is the price of the $i^{\text {th }}$ component in the $t^{\text {th }}$ year without VAT;

$\mathrm{Co}_{t_{i}}$ are operating costs for the $i^{\text {th }}$ component during its production during the development of the oil and gas field for the period $t_{e_{i}}$;

$I T_{t_{i}}$ is an income tax in the $\mathrm{t}^{\text {th }}$ period of development of oil and gas field;

$V_{F A_{t}}$ is fair value of fixed assets for the development of the field in the $t^{\text {th }}$ year; 
$V_{I A_{t}}$ is fair value of intangible assets used during the development of oil and gas resources in the $t^{\text {th }}$ year;

$k$ is the capitalization ratio of funds and intangible assets of the oil and gas field. The value of the capitalization ratio can be taken in the amount of 0.09 - the capital productivity ratio in the industries of energy materials extraction according to the State Property Fund of Ukraine [23, p. 51] or it is necessary to justify in each case, using appropriate methods for determining the capitalization rate, for example, through the discount rate.

We characterize the features of the formation of cash flows, accounting for the time factor and the features of their calculation in each of the periods.

The period of exploration and development of the field. This period begins with the pre-investment phase, which consists in obtaining the proper permits and approvals for the use of the land plots on which the field is located, conducting a complex of geological and geophysical work, geological and economic assessment of hydrocarbon resources, a feasibility study for the development of the field, well drilling, and arrangement of the field. During this period, investment expenses are capital expenditures, the return on which begins only with the start of exploitation of the oil and gas field. At the same time, we want to pay special attention to the fact that investment expenditures for this purpose must be compounded, and not discounted, as it was written out in the "Procedure and Criteria for Evaluating the Economic Efficiency of Project (Investment) Proposals and Investment Projects" [24]. Model (1) in this part is made in such a way that allows us to take into account the fact that the farther in time the investment costs for exploration are distant from the moment the oil and gas field is launched, the greater are the loss from freezing investments $\left[\sum_{t_{I C}=0}^{T_{e}} I_{t_{I_{C}}}\left(1+r_{b}\right)^{T e-t_{I C}}\right]$.

As for the basic rate of return that is used in compounding, the international practice of investment analysis most often adopts the rate of return of the so-called "risk-free assets" - long-term government bonds with a maturity of 10 years or more, since this type of investment is considered the least risky. Due to the unstable political and economic situation and the underdeveloped market environment in Ukraine, investment in government bonds is no reason to consider the least risky. Therefore, it's more reasonable to use rates of return, which are the most affordable and require minimal management from the investor as the basic ones when investing in alternative assets. Such assets are deposits for legal entities in freely convertible currency in leading Ukrainian commercial banks. The average rate of return was about $3.7 \%$ for this financial instrument in Ukraine in 2018 [25].

Payback period for investment in exploration of the field. This is the period during which the cumulative amount of cash inflow from extraction of oil and gas resources equals the amount of investment in exploration of the field. A feature of this period is that the cash flows and economic benefits that the investor receives during this period are usually used to pay off interest on borrowed funds, compensate for the increased costs of developing oil and gas fields, and bring technological, operational and economic indicators to levels established by development projects, etc.

At this stage, it is advisable to apply a full-fledged discounting procedure, bringing the cash flows to the moment of the start of operation, since the cash flows coming to the investor during this period can hardly be sent directly to the financial market or other alternative projects. That is, the cash flows received are practically frozen. Discounting of cash flows during this period should be carried out at a full discount rate, taking into account the principle of alternative investments and the risks of investing in this oil and gas field.

It is important to determine the full discount rate $(r)$, which should take into account: the stages of the exploration process of the field; type of hydrocarbon resources to be developed; natural and geographical conditions for the location of the field; complexity and features of the geological structure; depth of occurrence of deposits; reservoir properties; well productivity; characteristics of reservoir fluids, etc. In this case, there can be used the appropriate methodological approach was proposed in the following work [16]

The main operational period. This is the period during which the investor should receive the main economic benefits from the implementation of the project on the development of oil and gas field resources. To account for the time factor, cash flows must be brought to the beginning of this period by discounting.

However, it is erroneous to assume that the investor will immediately direct all the economic benefits received to alternative investment projects or the financial market, and therefore these cash receipts should be compounded until the end of the operating period, as offered in [17-20]. We believe that this approach is not entirely correct for the following reasons:

firstly, only net profit, its undistributed part, can be directed to the financial market. The other part, distributed profit, is used to pay dividends, environmental and social goals, especially in our time, which is declared by the international community as an era of socially oriented economy;

secondly, part of the implicit cash flows in the form of depreciation should be used according to their main purpose, that is, to maintain fixed assets in good condition during operation and for their renovation after the end of their useful life (operation) [21, p. 97].

Therefore, only part of retained earnings can be compounded, which is reflected in model (1). At the same time, saving retained earnings until the expiration of the deposit period must be carried out at the basic rate of return $\left(r_{b}\right)$.

In addition, it is necessary to take into account the risks of the project by applying the discount procedure. But there should be used a special discount rate $r_{n}$, which takes into account only the risks of the project and does not include the base rate, which takes into account the loss of value due to the possibility of alternative investment. After all, the oil and gas field has been developed, most of the investment costs have been made and it is incorrect to consider the 
possibilities of alternative investment. This feature the time factor at the longest period of development of oil and gas resources also significantly reduces the negative impact of the discount procedure.

In all periods, it is necessary to use real discount rates, that is, net of inflation according to the well-known Fisher formula, which also significantly mitigates the effect of compounding and discounting procedures on cash flows. In addition, the structure of assets and taxation conditions should be taken into account at the final stage of determining discount rates.

It should also be noted that there is another part of the investment costs $I_{t_{e}}$ that are incurred during operation for the development project of any oil and gas field during the payback and after payback periods. It is advisable to apply the discount procedure at the basic rate of income for them.

At all stages of developing the resources of oil and gas fields, the relevant institutions, infrastructure support and management mechanisms play an important role, and capitalization is impossible without them.

\section{CONCLUSIONS}

There has been proposed a new methodological approach to the capitalization of oil and gas resources in the subsoil that allows differentially taking into account the process of investing, obtaining economic benefits and the influence of the time factor at various stages of developing the resources of oil and gas fields. There are described features of determining the value of investment costs and cash flows at the main stages of exploration and development of oil and gas fields, taking into account the time factor. Further research should be directed to approbation of the proposed method of capitalization of oil and gas resources and improving methodological approaches to determining and substantiating the numerous parameters that are necessary when applying it.

\section{REFERENCES}

[1] V. M. Geitz et al., Capitalization of the Ukrainian economy. Kyiv, Ukraine: Institute of Economics and Forecasting, 2006. [in Ukrainian]

[2] M. A. Kozoriz, and G. V. Voznyak, "Capitalization of regional assets", Regional Economy, no. 1, pp. 251-253, 2010. [in Ukrainian].

[3] I. P. Buleev et al., Capitalization of enterprises: theory and practice: monograph. Donetsk, Ukraine: NAS of Ukraine, Institute of Industrial Economics, Donetsk University of Economics and Law, 2011. [Online]. Available: http://www.econindustry.org/SiteDocs/monograf. pdf. Accessed on: on August 17, 2019. [in Russian]

[4] B. V. Burkinsky, and V. F. Goryanchuk, Capitalization of the economy of the regions of Ukraine. Odessa, Ukraine: IPREED NAS of Ukraine, 2014. [in Ukrainian].

[5] M. G. Zinkovskaya, and T. V. Raeva, "Theoretical approaches to the concept of capitalization", New Science: Problems and Prospects, no. 10-1, pp. 130-136, 2016. [Online]. Available: https://ami.im/sbornik/MNPK-109-1.pdf. Accessed on: July 20, 2019. [in Russian].

[6] O. V. Shimko, "Current features of capitalization of oil and gas multinational companies in the USA", Candidate's thesis, MGIMO Univ., Moscow, Russian, 2017. [Online]. Available: https://mgimo.ru/science/diss/shimko_autoref.pdf. Accessed on: August 20, 2019. [in Russian].

[7] D. A. Alekseev, Mechanisms of company capitalization. Irkutsk, Russian: Publishing House of BSUEL, 2011. [Online]. Available: http://berezkin.info/wp-content/uploads/2011/02/Alekseev-
Mehanizmy-kapitalizacii.pdf. Accessed on: August 21, 2019. [in Russian].

[8] I. Y. Yaremko, and O. S. Lemishovskaya, "Corporate capitalization processes and their reporting", Bulletin of the National University of Lviv Polytechnic, no. 873, pp. 119-125, 2017. [in Ukrainian].

[9] V. V. Zymovets, and K. V. Bagatska, "The real sector of Ukrainian economy capitalization: trends and consequences", Scientific journal "World of Finance", no. 1(54), pp. 7-21, 2018. [Online]. Available: http://sf.tneu.edu.ua/index.php/sf/article/view/1039/1044. Accessed on: August 22, 2019. [in Ukrainian].

[10] M. A. Khvesyk et al., Capitalization of natural resources: monograph. Kyiv, Ukraine: NAS of Ukraine, SI "IENMSD of NAS of Ukraine", 2014. [in Ukrainian].

[11] S. I. Pyrozhkov et al., Economic valuation of Ukraine's natural wealth: monograph. Kyiv, Ukraine: NAS of Ukraine, SI "IENMSD of NAS of Ukraine", 2015. [in Ukrainian].

[12] V. S. Mishchenko Economic priorities for development of mineral resources of Ukraine. Kyiv, Ukraine: Scientific and Production Enterprise "Publishing House Scientific Thought, 2007. [in Ukrainian]. [in Ukrainian].

[13] I. K. Bystryakov, "Territorial natural and resource capital in ensuring the competitiveness of the Ukrainian economy", Socio-economic problems of the modern period of Ukraine, vol. 3(107), pp. 200-209, 2014. [in Ukrainian].

[14] I. K. Bystryakov, D. V.Klynovy, and L. V. Bodnar, "The algorithm of transformation of the management system of local natural resources", Journal of Kyiv University of Market Relations. Economy. Business administration. Right., no. 2(2), pp. 66-81, 2017. [in Ukrainian].

[15] V. M. Mandzyk, Water Capitalization: Theory and Practice: A Monograph. Kyiv, Ukraine: ProfKnyga, 2018. [in Ukrainian].

[16] O. V. Lebega, "Organizational and economic mechanism of development of natural gas resources from shale breeds", SHEE «Kyiv National Economic University named after Vadym Hetman», Kyiv, Ukraine, 2018. [in Ukrainian].

[17] Yu. A. Shekhovtsova, "On the Issue of Improving the Methodology for Discounting Cash Flows", Management in Russia and Abroad, no. 3, 2011. [Online]. Available: http://www.niec.ru/Articles/060.htm. Accessed on: August 20, 2019. [in Russian].

[18] K. N. Dmitriev, "Consideration of the Time Factor During Evaluating the Effectiveness of Large-Scale Investment Projects", Proceedings of ISA RAS, vol. 63.1, pp. 47-55, 2013. [Online]. Available: http://www.isa.ru/proceedings/images/documents/2013-63-1/t-1-13_ 47 -55.pdf. Accessed on August 17, 2019. [in Russian].

[19] V. B. Daskovsky, and V. B. Kiselev, "The Relevance of Improving the Economic Rationale for Investment", Investments in Russia, no. 5, pp. 3-16, 2014. [Online]. Available: http://www.niec.ru/ Articles/IVR201405Dask.pdf. Accessed on: August 17, 2019. [in Russian].

[20] V. B. Daskovsky, and V. B. Kiselev, "Phase Method of Taking Into Account the Time Factor in Solving Typical Practice Problems", Ekonomist, no. 3, pp. 17-29, 2015. [Online]. Available: http://www.niec.ru/Articles/081.htm. Accessed on: August 17, 2019. [in Russian].

[21] U. Ya. Vytvytska, "Development of Methodological Bases for Evaluating the Effectiveness of Investments", Economic analysis, vol. 26, no. 1, pp. 92-98, 2016. [in Ukrainian].

[22] L.G. Melnyk, and I. B. Degtyarova, "Accounting for Externalities in Managing the Development of the Productive Forces of Ukraine", in Intern. Scien. Conf. Development of the productive forces of Ukraine: from V. I. Vernadsky to the present, Kyiv, 2009, p. 1, pp. 95-97. [in Ukrainian].

[23] State Property Fund of Ukraine. (2004, Febr. 5). No. 236, Order. State Privatization Bulletin , no. 4, p. 51, 2004. [in Ukrainian].

[24] The Cabinet of Ministers of Ukraine. (2012, Jul. 18). No. 684, Resolution "On Approval of the Procedure and Criteria for Evaluating the Economic Efficiency of Project (Investment) Proposals and Investment Projects". [Online]. Available: http://zakon2.rada.gov.ua/laws/show/ 684-2012-n. [in Ukrainian].

[25] Analytical review of Ukrainian banks. Deposits. [Online]. Available: http://bankografo.com/analiz-bankiv/bankivska-statystyka/depozitnistavki/klasichni-depoziti-protsentni-stavki. Accessed on: July 10, 2019. [in Ukrainian]. 